\title{
Physiological attributes of tomato (Lycopersicon esculentum M ill.) influenced by different sources of nutrients at foothill of eastern Himalayan region
}

\author{
Ranjit Chatterjee
}

Department of Vegetable and Spice Crops, Uttar Banga Krishi Viswavidyalaya, Pundibari, Cooch Behar (West Bengal), INDIA E-mail: ranchat22@rediffmail.com

Received: M ay 1, 2013; Revised recei ved: J une 7, 2013; Accepted: J uly 5, 2013

Abstract: The present investigation was aimed to assess the influence of different organic manures (Farmyard manure and vermicompost), inorganic fertilizers and Azophos biofertilizer on different physiological attributes of tomato. The field experiment was conducted during 2005-06 and 2006-07 at Uttar Banga Krishi Viswavidyalaya (UBKV), Pundibari, Cooch Behar, West Bengal, India by combining 14 treatments in randomized block design with 3 replications. The results revealed that nutrient sources significantly influenced different physiological attributes as the chlorophyll content of leaves and LAI (Leaf area index) kept on increasing and peaked at 60 DAT(Days after transplanting) and 75 DAT respectively and declined thereafter. The dry matter production was highest at 75 DAT. Again application of vermicompost ( $4 \mathrm{t} / \mathrm{ha}$ ) with $75 \%$ of inorganic fertilizers inoculated with biofertilizer resulted in significant improvement of physiological attributes as well as yield. Vermicompost emerged as better organic nutrient source over farmyard manure. Inoculation with biofertilizer exerted more positive results over uninoculated treatments and benefits of biofertilizer application were more in presence of vermicompost as compared to farmyard manure.

Keywords: Biofertilizer, Farmyard manure, Inorganic fertilizers, Physiological attributes, Tomato, Vermicompost

\section{INTRODUCTION}

Tomato (Lycopersicon esculentum Mill.) is consumed fresh or utilized in preparation of wide range of processed products. The ripe fruits provide an excellent source of vitamins, minerals and antioxidants which protects human body from oxidative damages that may lead to heart disease, cancer and ageing. The fruit yield depends in the capacity of the plant to accumulate and translocate the photosynthates towards the sink (De et al., 2008). The physiological attributes viz. chlorophyll content of leaves, leaf area index (LAI) and dry matter accumulation are closely related with the plant growth and have considerable bearing on yield attributes and fruit yield of tomato. The nutritional status of the soil plays significant role in modification and improvement of different physiological attributes (Roy and Chakraborty, 1993). The incorporation of organic nutrients in the form of vermicompost, farmyard manure and biofertilizer is known to influence favourably to the physico chemical and biological properties of the soil thus resulting in enhanced crop growth and yield (Gour, 1992). Vermicompost, organic manure obtained in the form of casting of ingested biomass by earthworm after undergoing physical, chemical and microbial transformations. Besides macro and micronutrients it also contains humic acids, plant growth promoting substances like auxins, gibberellins, and cytokinins (Krishnamoorthy and Vajrabhiah, 1986), N-fixing and P-solubilizing bacteria, enzymes and vitamins (Ismail, 1997). The water soluble components of vermicompost such as humic acid, growth regulators, vitamins, micronutrients and beneficial microorganism increases the availability of plant nutrients, results in increased growth, higher yield and better quality produce (Atiyeh et al., 2002). In addition to vermicompost, farmyard manure and biofertilizer also play vital role as organic nutrient sources for sustainable soil health and crop growth (Mali et al., 2005). Incorporation of more organic nutrients were found effective in increasing the growth and yield parameters through enhanced biomass production and translocation of assimilates toward developing sink. Some studies suggested that higher amount of organic sources of nutrients and reduced level of inorganic fertilizers can enhance the physiological efficiency of pea (Reddy et al., 1998) and okra (Paramasivan, 2005). In light of the fact, the present experiment was undertaken to study the influences of different sources of nutrients and their combination on important physiological attributes and subsequently on yield attributes and fruit yield of tomato.

\section{MATERIALS AND METHODS}

The field experiment was conducted at the experimental field of Uttar Banga Krishi Viswavidyalaya (UBKV), 
Pundibari, CoochBehar, West Bengal (89²3' 53" E longitude and 2619'86" N latitude) during winter season (November to March) of 2005-2006 and 2006-2007. The soil was well drained sandy loam having $\mathrm{pH}$ of 5.74 , organic carbon content $0.85 \%$ and available $\mathrm{N}, \mathrm{P}_{2} \mathrm{O}_{5} \mathrm{~K} 2 \mathrm{O}$, were $155.85 \mathrm{~kg} / \mathrm{ha}, 20.23 \mathrm{~kg} / \mathrm{ha}$ and $125.90 \mathrm{~kg} / \mathrm{ha}$ respectively (Chatterjee, 2009). The treatment consisted of 14 combinations of different nutrient sources and was laid out in randomized block design with three replications. The treatments were selected for sole and combined application of varied levels of vermicompost and farmyard manure (FYM) along with 100\% and $75 \%$ of recommended dose of inorganic fertilizers in presence and absence of biofertilizer. The combinations were $\mathrm{T}_{1}$ $100 \%$ Recommended fertilizer dose (R.F.D.) (100:60:60 kg N P K /ha) ; $\mathrm{T}_{2}-100 \%$ R.F.D. +6 tonnes FYM/ha + biofertilizer ; $\mathrm{T}_{3}-100 \%$ R.F.D. +2 tonnes vermicompost/ ha + biofertilizer ; $\mathrm{T}_{4}-100 \%$ R.F.D. +3 tonnes FYM/ha +1 ton vermicompost/ha + biofertilizer $; \mathrm{T}_{5}-75 \%$ R.F.D. +6 tonnes FYM/ha ; $\mathrm{T}_{6}-75 \%$ R.F.D. +6 tonnes FYM/ha + biofertilizer $; \mathrm{T}_{7}-75 \%$ R.F.D. +2 tonnes vermicompost $/$ ha $; \mathrm{T}_{8}-75 \%$ R.F.D. +2 tonnes vermicompost/ha + biofertilizer ; $\mathrm{T}_{9}-75 \%$ R.F.D. +3 tonnes FYM/ha +1 ton vermicompost/ ha + biofertilizer $; \mathrm{T}_{10}-75 \%$ R.F.D. +12 tonnes FYM/ha ; $\mathrm{T}_{11}-75 \%$ R.F.D. +12 tonnes FYM/ha+ biofertilizer ; $\mathrm{T}_{12}{ }^{-}$ $75 \%$ R.F.D. +4 tonnes vermicompost $/$ ha $; \mathrm{T}_{13}-75 \%$ R.F.D. +4 tonnes vermicompost/ha + biofertilizer and $\mathrm{T}_{14}-75 \%$ R.F.D. +6 tonnes FYM/ha +2 tonnes vermicompost $/ \mathrm{ha}+$ biofertilizer. Tomato seedlings (cv. Pusa Ruby) were transplanted in $3.75 \mathrm{~m} \times 3.75 \mathrm{~m}$ plots with a spacing of 75 $\mathrm{cm}$ within and between rows. Vermicompost and farmyard manure were applied to the respective plots at the time of transplanting. Azophos, the Azotobacter and phosphate solubilizing bacteria containing biofertilizer was applied as seedling dipping $(250 \mathrm{~g} /$ litre water $)$ just before transplanting. Full dose of $\mathrm{P}_{2} \mathrm{O}_{5}$ and $\mathrm{K}_{2} \mathrm{O}$ along with half $\mathrm{N}$ were applied as basal and rest $\mathrm{N}$ was top dressed at 30 days after transplanting. The crop was raised adopting standard cultural practices. The physiological attributes were recorded at periodic interval of 30, 60, 75, 90 and 105 DAT (Days after transplanting). The chlorophyll content of tomato leaves was measured by using portable leaf chlorophyll meter (Minolta, Japan) and express in terms of SPAD 502 value. The leaf area index (LAI) was determine with standard procedure after measuring the area of leaves by using leaf area meter (Model 22, Systronics).To estimate dry matter, fresh whole plant samples were dried individually till constant weight was recorded. The data was analyzed statistically with the help of INDOSTAT statistical package.

\section{RESULTS AND DISCUSSION}

Physiological parameters

Chlor ophyll content of leaves: The results revealed that chlorophyll content of tomato leaves showed increasing trend from vegetative to flowering phase and reached its peak at $60 \mathrm{DAT}$, thereafter it showed decline trend towards maturity of the crop for all the treatments, irrespective of treatment combinations (Table 1). At 30 DAT, the highest chlorophyll content of tomato leaves (42.40) was recorded for the plants received only sole chemical fertilizers $\left(\mathrm{T}_{1}\right)$. Increased nitrogen assimilation due to adequacy of instant nitrogen ion might have increased the chlorophyll content of tomato leaves at early stage. This was followed by the treatments $\mathrm{T}_{3}, \mathrm{~T}_{4}$ and $\mathrm{T}_{2}$. At 45 DAT unlike 30 DAT, the higher chlorophyll content of tomato leaves was recorded by integrated application of inorganic, organic and biological sources of nutrients and the highest value (49.30) was measured by the treatment $\left(\mathrm{T}_{3}\right)$.Although it was statistically at par with the treatments $\mathrm{T}_{4}$ and $\mathrm{T}_{13}$. Higher chlorophyll content by the treatment $\mathrm{T}_{3}$ at this stage may be due to supply of continuous and gradual release of nutrients by the combined effect of $100 \%$ chemical fertilizers along with vermicompost and biofertilizer. At 60 DAT the maximum chlorophyll content of tomato leaves (59.40) was recorded by the treatment $\mathrm{T}_{13}$ followed by the treatments $\mathrm{T}_{12}$ and $\mathrm{T}_{3}$. The treatment $\mathrm{T}_{12}$ and $\mathrm{T}_{3}$ were statistically at par to each other, whereas the treatment $T_{13}$ was statistically superior over both the treatment. From 75 DAT onward the chlorophyll content of tomato leaves showed a decline trend for all the treatments, irrespective of treatment combinations may be due to utilization or mobilization of nutrients for the development of fruits, instead of growth of leaves. However the highest chlorophyll content of tomato leaves at 75 DAT (53.60), 90 DAT (48.30) and 105 DAT (43.60) were observed for the treatments $T_{13}$ followed by the treatment $\mathrm{T}_{12}$ and $\mathrm{T}_{14}$. Highest chlorophyll content of tomato leaves by the treatment $T_{13}$ at these stages may be due to the favourable effect of higher amount of organic manure in the form of vermicompost along with inorganic fertilizers and biofertilizer resulted in enhanced absorption of nutrients and effective conversion of the nutrients into pigments resulted in accumulation of more chlorophyll in the leaves. The results are in conformity with El-Sabour et al., 1997 who also found increased chlorophyll content of leaves in Helianthus annus (sunflower) when soil was treated with organic compost Vignesh et al. (2012) observed increased chlorophyll concentration and antioxidant activity of spinach leaves under organic fertilizer amendments.

L eaf ar ea index ( $\mathrm{LAI}$ ): The observation recorded on leaf area index of tomato (Table 1) at successive growth stages of tomato $(30,45,60,75,90$ and 105 DAT) revealed that LAI was low at the early stages of crop growth and kept on increasing with the advancement of age of the tomato plant till 75 days when it reaches its peak and thereafter LAI showed declining trend towards maturity for all the 


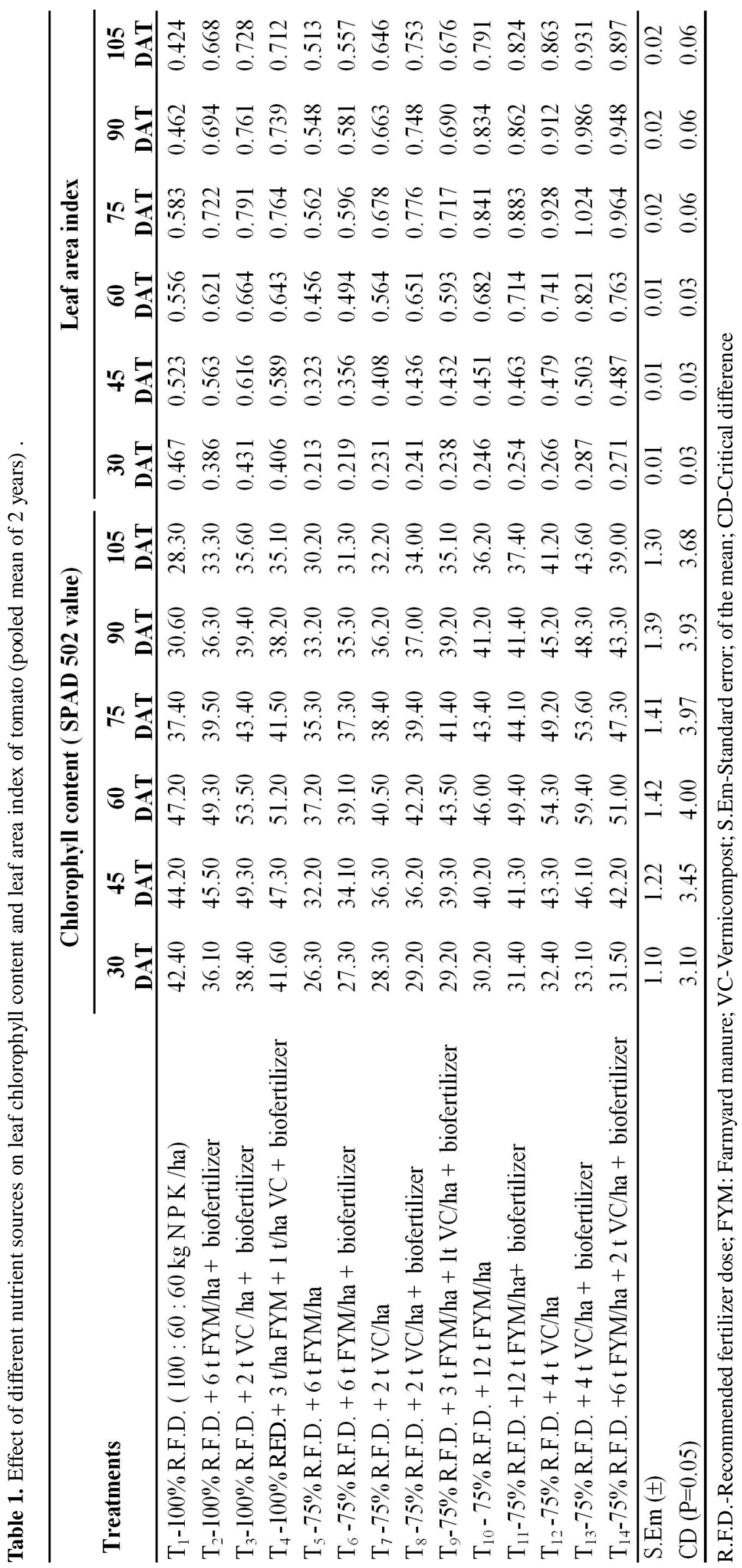


treatments. At 30 DAT the LAI value of tomato was the lowest among all the growth stages however, the highest LAI (0.467) was obtained in the treatment $\mathrm{T}_{1}$ and was significantly superior over rest of the treatments. This was followed by the treatments $T_{3}$ and $T_{4}$. The highest LAI of tomato with the treatment $\mathrm{T}_{1}$ may be due to the direct effect of straight fertilizer particularly nitrogen. At 45 DAT the LAI of tomato kept on increasing for all the treatments and unlike 30 DAT the higher leaf area index was recorded by integrated application of inorganic fertilizer in combination with organic and biological sources of nutrients and the highest value (0.616) was measured by the treatment $T_{3}$ followed by the treatments $\mathrm{T}_{4}$ and $\mathrm{T}_{2}$. Highest LAI of tomato by the treatment $\mathrm{T}_{3}$ could be attributed to increased nitrogen supply, which might have promoted synthesis of new leaves led to higher LAI at this stage. At 60 DAT increasing trend of LAI of tomato was observed among the different treatments and unlike 45 DAT, the highest LAI (0.821) was obtained for the treatment $\mathrm{T}_{13}$ followed by the treatments $T_{14}$ and $T_{12}$. The treatment $T_{14}$ and $T_{12}$ were statistically at par to each other, whereas the treatment $\mathrm{T}_{13}$ was statistically superior over all the treatments. At 75 DAT the highest value of LAI of tomato was measured among the different growth stages for all the treatments irrespective of treatment combination. The maximum LAI (1.024) was noticed for the treatment $T_{13}$ followed by the treatments $\mathrm{T}_{14}$ and $\mathrm{T}_{12}$. Unlike $75 \mathrm{DAT}$, the LAI at $90 \mathrm{DAT}$ and 105 DAT starts declining for all the treatments irrespective of treatment combinations. However the highest LAI of tomato at 90 DAT (0.986) and 105 DAT (0.931) was recorded for the treatment $T_{13}$ followed by the treatments $\mathrm{T}_{14}$ and $\mathrm{T}_{12}$. Maximum LAI by the treatment $\mathrm{T}_{13}$ could be attributed to the favourable effect of higher amount of organic manure in the form of vermicompost in combination with inorganic fertilizers and biofertilizer. Again Azophos in presence of vermicompost would have enhanced the synthesis of growth hormones and improved the nitrogen fixing ability as well as mobilizing the phosphorus of the soil. All these factors led to production of more number of leaves and higher leaf area, ultimately greater leaf area index in tomato plants. Rao and Sankar (2001) established that higher amount of organic sources of nutrients enhanced the leaf number and subsequently the leaf area index in brinjal.

Dry matter accumulation (g/plant): The dry matter accumulation (DMA) of tomato at 30, 45, 60, 75, 90 and 105 DAT were presented in Table 2. The experimental results showed that there was a progressive increase in DMA from vegetative to reproductive phase. The initial dry matter production was low at vegetative stage and was triggered as the crop approached towards reproductive phase. At $30 \mathrm{DAT}$, the accumulation of dry matters was the lowest among all other growth stages and the highest DMA (21.46 g) was observed in the treatment $T_{1}$ followed by the treatments $T_{3}, T_{4}$ and $T_{2}$. The treatment $T_{1}$ was significantly superior over all the treatments whereas the treatment $\mathrm{T}_{3}, \mathrm{~T}_{4}$ and $\mathrm{T}_{2}$ were statistically at par to each at this stage. The faster rate of DMA of tomato with the treatment $T_{1}$ might be due to increased nitrogen uptake resulted in increased synthesis of photosynthetes and enhanced the plant vegetative growth at early stages of crop growth. At 45 DAT the dry matter accumulation kept on increasing for all the treatments and the highest DMA of tomato was recorded by the treatment $T_{3}(46.52 \mathrm{~g})$ followed by the treatments $\mathrm{T}_{4}$ and $\mathrm{T}_{2}$. At $60 \mathrm{DAT}$ increasing trend of DMA of tomato was noticed among all the treatments and unlike 45 DAT the treatment $\mathrm{T}_{13}$ recorded the maximum DMA of tomato $(69.71 \mathrm{~g})$ followed by the treatments $\mathrm{T}_{14}$ and $\mathrm{T}_{12}$. The treatment $T_{13}$ was significantly superior over all other treatment and the treatments $\mathrm{T}_{12}$ and $\mathrm{T}_{14}$ were statistically at par to each other at this stage. At 75 DAT significant improvement of DMA of tomato was observed for all the treatments which were highest among all the growth stages, irrespective of treatment combinations. The treatment $\mathrm{T}_{13}$ recorded maximum DMA of tomato (128.34 g) at this stage, which was $51 \%$ higher over the sole $100 \%$ inorganic fertilizers $\left(\mathrm{T}_{1}\right)$. This was followed by the treatments $T_{14}$ and $T_{12}$. At 90 DAT and 105 DAT, the increasing trend of the DMA of tomato was noticed for all the treatments irrespective of treatment combination. The maximum DMA of tomato at 90 DAT $(189.26 \mathrm{~g})$ and 105 DAT (226.58 g) were observed for the treatment $\mathrm{T}_{13}$ which was followed by the treatments $T_{14}$ and $T_{12}$. The treatment $\mathrm{T}_{13}$ was statistically superior over all other treatments at this stage, while the treatments $\mathrm{T}_{14}$ and $\mathrm{T}_{12}$ were statistically at par to each other. Dass et al. (2008) in their experiment with Navjyoti variety of tomato recorded $243.90 \mathrm{~g}$ DMA at first picking when $50 \%$ of recommended dose of fertilizer (100:50:50 kg NPK /ha) and 5 tonnes vermicompost /ha was applied compared to $109.80 \mathrm{~g}$ under control. The superiority of the integrated application of nutrients may be due to the positive response of organic, inorganic and biological sources of nutrients combination in increasing the translocation and accumulation of photosynthetes in the plants. Again the efficacy of vermicompost supposed to be enhanced due to certain hormonal activity associated with it. All these might have promoted the development of growth parameters like production of more number of roots, branches and leaves and exhibited better plant vigour that subsequently contributed to greater dry matter accumulation.

Y ield attributes and yield: The yield attributing characters were significantly influenced by combined application of inorganic, organic and biological sources of nutrients. The results (Table 2) showed that the 


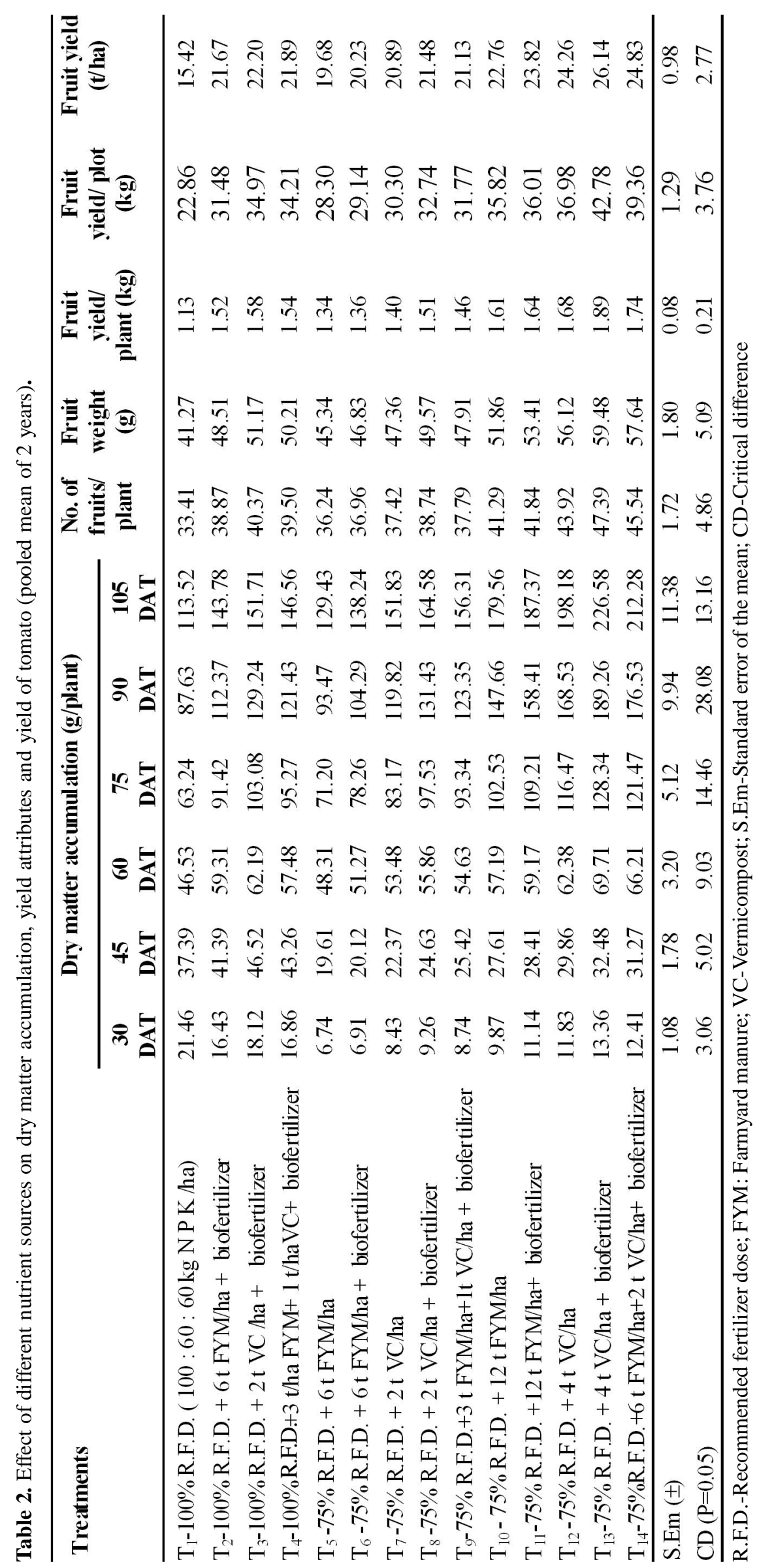


integration of $75 \%$ of recommended inorganic fertilizer along with higher amount of organic manures have surpassed the treatments having $100 \%$ inorganic fertilizers combination. Application of 4 tonnes vermicompost per hectare in conjugation with $75 \%$ of recommended inorganic fertilizer and biofertilizer $\left(\mathrm{T}_{13}\right)$ recorded the maximum number of fruits per plant (47.39), average fruit weight $(59.48 \mathrm{~g})$, highest fruit yield per plant $(1.89 \mathrm{~kg})$ and per plot $(42.78 \mathrm{~kg})$ as well as per hectare (26.14 ton). However the treatments $\mathrm{T}_{14}$ and $\mathrm{T}_{12}$ were statistically at par with the treatment $\mathrm{T}_{13}$ for all these yield characters. The treatment $\mathrm{T}_{13}$ recorded $41.84 \%$ more number of fruits, $44.12 \%$ higher fruit weight and $67.26 \%$ greater fruit yield per plant over the treatment $\mathrm{T}_{1}$. The results further revealed that among the $75 \%$ inorganic fertilizer treatment combination, yield attributes were significantly influenced by the form and level of the organic manures and higher levels of vermicompost performed better over higher levels of farmyard manure. Again the performance of biofertilizer was influenced by the forms and levels of organic manures. In case of higher level of farmyard manure, presence of biofertilizer $\left(\mathrm{T}_{11}\right)$ resulted $2 \%$ more fruit yield over the uninoculated treatment combination $\mathrm{T}_{10}$, where as for higher level of vermicompost, addition of biofertilizer $\left(\mathrm{T}_{13}\right)$ resulted in $11 \%$ improvement in fruit yield over the uninoculated treatment combination $\mathrm{T}_{12}$. These findings indicated that combined application of vermicompost, inorganic fertilizers and biofertilizer have pronounced influenced on yield attributes of tomato. The increased fruit yield under integrated use of higher amount of vermicompost and reduced level of inorganic fertilizer in presence of biofertilizer may be due to large uptake of nutrients and effective utilization of these nutrients for increased synthesis of carbohydrates, greater vegetative growth and subsequently better partitioning and remobilization of accumulated assimilates towards developing fruits (sink). Enhanced growth parameters and higher head yield in tomato under diverse nutrient sources was earlier reported by Patil et al., 1998 and Das et al., 2008.

\section{Conclusion}

The present study revealed that integrated use of different source of nutrients enhanced the desirable physiological traits such as higher chlorophyll content, larger leaf area index and greater dry mater content of tomato which subsequently imparted the desirable fruit weight and yield of tomato. Partial substitution of inorganic fertilizers through vermicompost is highly effective and higher levels of vermicompost emerged as better organic source over that of farmyard manure. Application of biofertilizer exerted more benefits over the uninoculated treatments.

\section{REFERENCES}

Atiyeh, R.M., Lee, S.S., Edwards, C.A., Arancon, N.Q. and Metzger, J. (2002). The influence of humic acid derived from earthworm-processed organic waste on plant growth Bioresource Technology, 84: 7-14.

Chatterjee, Ranjit (2009). Production of vermicompost from vegetable wastes and its effect on integrated nutrient management for vegetable production. Ph.D. Thesis, UBKV, Pundibari, West Bengal.

Dass, A., Lenka, N. K., Sudhishri, S. and Patnaik, U. S. (2008). Influence of integrated nutrient management on production, economics and soil properties in tomato under on farm condition in eastern ghat of Orissa. Indian Journal of Agricultural Sciences, 78 (1): 40-43.

De, N., Ram, D. and Pandey, S. (2008). Physiological traits as determinant of yield in muskmelon under field condition. Indian J ournal of Horticulture, 65 (1):40-43.

El-Sabour, A.M.F., Abo, E.S. and Rizk, M.A. (1997). Physiological and chemical responses of sunflower to the application of previous organic waste composts to sandy soil. Environmental M anagement and Health, 8:128-132.

Gour, A.C. (1992). Bulky organic manures and crop residues. In: H.L.S.Tandon (ed.), Fertilizers, Organic manures, Recyclable wastes and Biofertilizer, F.D.C.O publication, New Delhi. pp. 36-53

Ismail, S. A. (1997). Vermicology the biology of earthworms. Orient Longman, Hyderabad, India. pp. 92

Krishnamoorthy, R.V. and Vajrabhiah, S.N. (1986). Biological activity of earthworm casts : an assessment of plant growth promoter levels in casts. Proceedings of the Indian Academy of Science (Animal Science), 95: 341-351.

Mali, M. B., Musmade, A. M., Kulkarni, S. S., Prabu, T. and Dirade, R. M. (2005). Effect of organic manure on yield and nutrient uptake of cucumber cv. Himangi. South Indian Horticulture, 53 (1/6):110-115.

Paramasivan, M., Jawahar, D. and Krishnamoorthi, V. V.(2005). Effect of organic manures and inorganic fertilizers on yield and economics of okra in an alfisol of Tambiraparani tract. South Indian Horticulture, 53 (1-6):312-315.

Patil, M. P., Hulamani, N. C., Athani, S. I. and Patil, M. G.(1998). Response of new tomato genotype Megha to integrated nutrient management. Advances in Agricultural Research in India, 9:39-42.

Rao, T. S. S. S. and Sankar, C. R. (2001). Effect of organic manures on growth and yield of brinjal. South Indian H orticulture, 49 (Special): 288-291.

Reddy, R., Reddy, M., Reddy, Y., Reddy, T. N. and Anjanappa, M. (1998). Effect of organic and inorganic sources of NPK on growth and yield of pea (Pisum sativum). Legume Research, 24(1): 207-208.

Roy, S. K. and Chakroborty, A. K. (1993).Vegetables of tropical climate-commercial and dietary importance, In: R. M MacRae; R. K. Robinson. and M. J. Sandler.(ed). Encyclopaedia of Food Science, Food Technology and Nutrition J ournal, Academic press, London. pp. 715

Vignesh, R., Venkatesh, N.R., Meenakshisundaram, B. and Jayapradha, R. (2012). Novel instant organic fertilizer and analysis of its growth effects on spinach. J ournal of Biological Sciences, 12:105-110. 